\title{
Pinus flexilis and Picea engelmannii share a simple and consistent needle endophyte microbiota with a potential role in nitrogen fixation
}

\section{Alyssa A. Carrell and Anna C. Frank*}

Life and Environmental Sciences and Sierra Nevada Research Institute, School of Natural Sciences, University of California, Merced, Merced, CA, USA

\section{Edited by:}

Johan Leveau, University of California, Davis, USA

\section{Reviewed by:}

Devin Coleman-Derr, Joint Genome Institute, USA

Ann E. Stapleton, University of North Carolina at Wilmington, USA

\section{${ }^{*}$ Correspondence:}

Anna C. Frank, Life and Environmental Sciences and Sierra Nevada Research Institute, School of Natural Sciences, University of California, Merced, 5200 North Lake Road, Merced, CA 95343, USA

e-mail: cfrank3@ucmerced.edu
Conifers predominantly occur on soils or in climates that are suboptimal for plant growth. This is generally attributed to symbioses with mycorrhizal fungi and to conifer adaptations, but recent experiments suggest that aboveground endophytic bacteria in conifers fix nitrogen ( $\mathrm{N}$ ) and affect host shoot tissue growth. Because most bacteria cannot be grown in the laboratory very little is known about conifer-endophyte associations in the wild. Pinus flexilis (limber pine) and Picea engelmannii (Engelmann spruce) growing in a subalpine, nutrient-limited environment are potential candidates for hosting endophytes with roles in $\mathrm{N}_{2}$ fixation and abiotic stress tolerance. We used 16S rRNA pyrosequencing to ask whether these conifers host a core of bacterial species that are consistently associated with conifer individuals and therefore potential mutualists. We found that while overall the endophyte communities clustered according to host species, both conifers were consistently dominated by the same phylotype, which made up 19-53\% and $14-39 \%$ of the sequences in $P$. flexilis and $P$. engelmannii, respectively. This phylotype is related to Gluconacetobacter diazotrophicus and other $\mathrm{N}_{2}$ fixing acetic acid bacterial endophytes. The pattern observed for the P. flexilis and $P$. engelmannii needle microbiota-a small number of major species that are consistently associated with the host across individuals and species - is unprecedented for an endophyte community, and suggests a specialized beneficial endophyte function. One possibility is endophytic $\mathrm{N}$ fixation, which could help explain how conifers can grow in severely nitrogen-limited soil, and why some forest ecosystems accumulate more $\mathrm{N}$ than can be accounted for by known nitrogen input pathways.

\section{Keywords: bacterial endophytes, 16S rRNA, conifers, Pinus, Picea, nitrogen, Acetobacteraceae, subalpine}

\section{INTRODUCTION}

Bacterial endophytes inhabit the below- and aboveground tissues of all terrestrial plants examined and can affect plant physiology and growth under normal and stressed conditions. Endophytic bacteria can stimulate plant growth directly through production of phytohormones and volatiles (Arshad and Frankenberger, 1991; Ping and Boland, 2004; Hardoim et al., 2008), enhance nutrient acquisition (Hurek et al., 2002; Boddey et al., 2003), and suppress stress-induced ethylene synthesis (Glick, 2004). Bacterial endophytes have also been found to protect against disease (Conn et al., 2008), and against abiotic stress such as salinity, and heavy metals (Idris et al., 2004; Mayak et al., 2004). At the ecosystem level, bacterial endophytes can persistently alternate soil biogeochemical cycles through the support of invasive plants (Rout et al., 2013).

Research to date on bacterial endophytes has focused mainly on agricultural ecosystems (Hallman et al., 1997), and to some extent, on invasive plants (Rout et al., 2013). Our knowledge of the role, diversity, and transmission of bacterial endophytes colonizing native plants is still limited. However, plant-beneficial endophytic properties are likely to have evolved in, and continually influence plants in natural ecosystems. A better understanding of the bacteria that inhabit wild plants has the potential to impact our understanding not only of basic plant physiology, but also of whole ecosystem processes such as carbon (C) and $\mathrm{N}$ cycling.

While it is well established that many forest conifers depend on associations with mycorrhizal- (Smith and Read, 2008) and foliar endophytic fungi (Carroll, 1988; Arnold et al., 2003; Higgins et al., 2011), our understanding of the bacterial endophytes of conifers is limited (Pirttilä and Frank, 2011). Bacteria have been isolated from the interior of roots, stems, needles, seeds, and tissue culture of conifers (Pirttilä et al., 2000; Cankar et al., 2005; Izumi et al., 2008; Bal et al., 2012). Bacteria in the genus Methylobacterium likely play a role in the shoot tissue development of $P$. flexilis (Pirttilä et al., 2004, 2005). $\mathrm{N}_{2}$ fixing bacteria isolated from stems and needles of Pinus contorta have been found to increase the uptake atmospheric $\mathrm{N}_{2}$ in inoculated seedlings relative to control seedlings (Bal and Chanway, 2012; Anand and Chanway, 2013). A similar experiment on poplar clones inoculated with a consortium of $\mathrm{N}_{2}$ fixing bacteria suggests that $\mathrm{N}$ allocated to the leaves and stem in the poplar clones were derived largely from biological nitrogen fixation (Knoth et al., 2013). These results raise numerous questions: do non-nodulated trees in natural ecosystems acquire their $\mathrm{N}$ from endophytic $\mathrm{N}_{2}$ fixation? If so, are associations random 
or stable, and do single species or consortia of $\mathrm{N}_{2}$ fixing bacteria fix $\mathrm{N}_{2}$ ? Finally, does endophytic $\mathrm{N}_{2}$ fixation, along with other recently discovered nitrogen input pathways (DeLuca et al., 2002; Morford etal., 2011; Vitousek etal., 2013) explain the hidden input of $\mathrm{N}$ in temperate and boreal forests (Bormann et al., 1993, 2002; Binkley et al., 2000)? Unfortunately, a culturebased and experimental approach to answering these questions may not yet be feasible. Large discrepancies in the composition between cultured and uncultured endophytic communities (Ando et al., 2005) suggest that most bacterial endophytes may resist cultivation. In addition, there is no guarantee that an isolated species represents a dominant member of the endophytic community.

In general, sequence-based methods may be necessary to uncover some of the hidden symbioses in terrestrial ecosystems (Poole et al., 2012). High-throughput sequencing of the 16S rRNA can be used to identify the core subset of bacterial taxa present in the majority of host individuals, habitats, seasons, environments or developmental stages (Qin et al., 2010; Martinson et al., 2011; Lundberg et al., 2012; Rastogi et al., 2012; Sharp et al., 2012). Such core taxa often provide specialized beneficial functions to a host. In insect guts for example, a simple (i.e., consisting of few species) and consistent (i.e., present in all host individuals examined) microbiota typically plays a role in host nutrient acquisition (Engel and Moran, 2013). Once established, the role of core uncultured members of the community can be further evaluated using in situ methods (Sharp et al., 2012; Woebken et al., 2012).
Here, we used pyrosequencing of the 16S rRNA gene with the goal of identifying the core subset of bacterial species inside needles that are consistently associated with individuals of a conifer host species. Specifically, we asked whether the needle microbiota is conserved across individuals and stands of the high-elevation, stress-tolerant conifer species $P$. flexilis (limber pine) growing within one geographic area (Niwot Ridge in the Front Range of the Rocky Mountains, CO, USA), and whether the P. flexilis needle microbiota is shared with the co-occurring species $P$. engelmannii (Engelmann spruce).

This first comprehensive analysis of the bacterial endophyte microbiota in a gymnosperm revealed that the composition of $P$. flexilis and $P$. engelmannii needle endophyte communities is simple at the species level; that both conifer hosts are consistently dominated by potential $\mathrm{N}_{2}$ fixing taxa in the family Acetobacteraceae; and that the microbiota is largely shared between the two host species. We discuss the implications of these results in light of recent findings that bacterial endophytes appear to fix $\mathrm{N}_{2}$ inside conifer tissues in an experimental system.

\section{MATERIALS AND METHODS SAMPLE COLLECTION AND STERILIZATION}

Needles were collected from 14 trees at two elevations in the subalpine forest at Niwot Ridge, CO in September 2009-at tree line (TL) and near the local warm edge (WE) limit of the P. flexilis and $P$. engelmannii distributions (Table 1). To assess the difference in

Table 1 | Samples successfully characterized by $16 \mathrm{~S}$ rRNA in this study, along with the number of sequences after sequence quality control and removal of plant DNA.

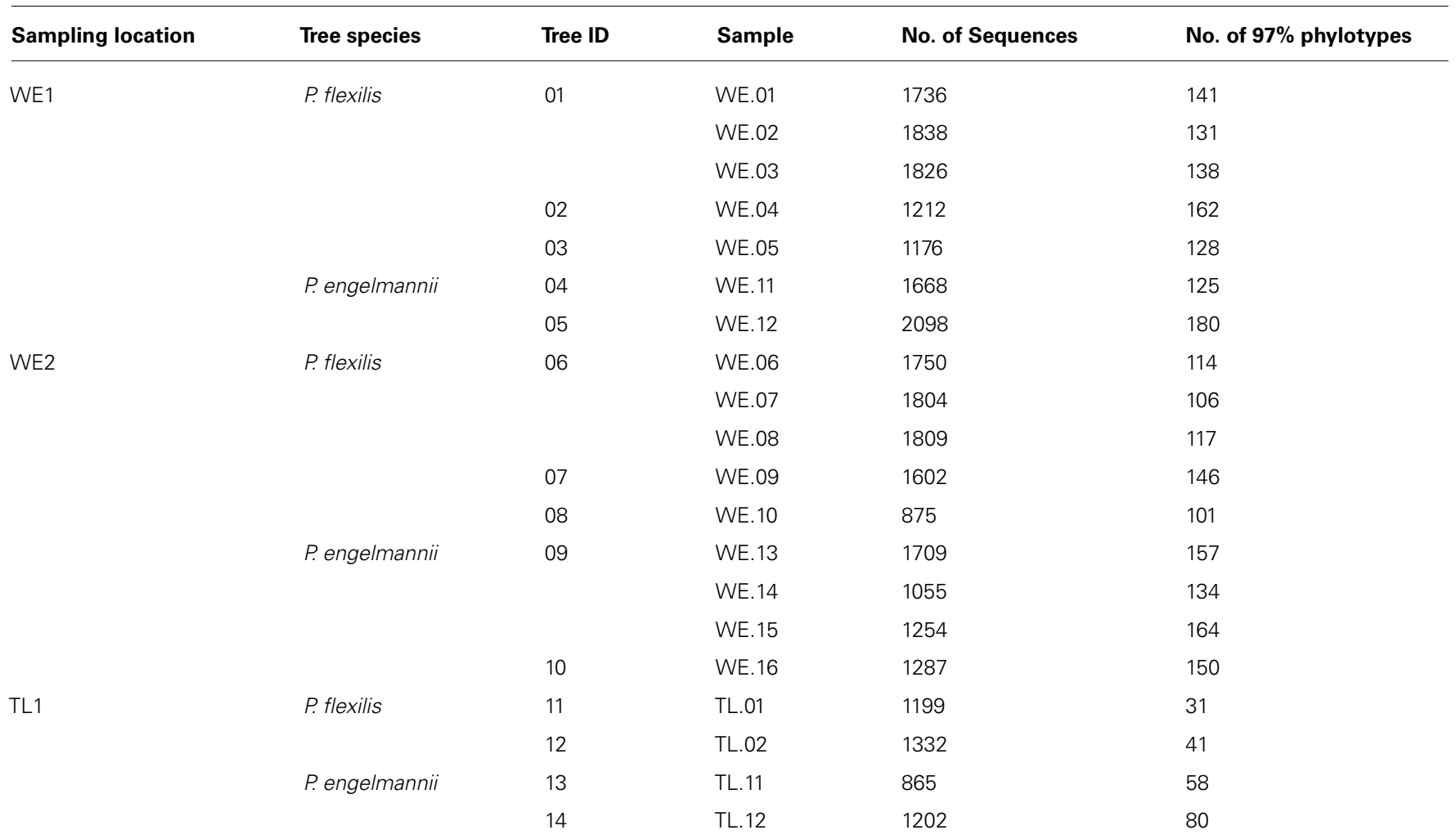


endophytic communities across locations, six $P$. flexilis and six $P$. engelmannii trees were sampled at two separate WE stands (WE1 and WE2), approximately $0.5 \mathrm{~km}$ apart. To contrast inter- and intra tree variation in the endophytic community, one individual of each tree species at each stand was sampled in triplicate. Additionally, two $P$. flexilis and two $P$. engelmannii individuals were sampled at treeline, the upper elevation limit of upright tree growth. From each sampled tree, approximately $10 \mathrm{~g}$ of needles were removed with a sterile razor blade, placed in a sterile bag, and shipped to the University of California, Merced at $4^{\circ} \mathrm{C}$ for sterilization and extraction. Needles were sterilized through submersion in ethanol for one minute, $30 \%$ hydrogen peroxide for $3 \mathrm{~min}$, followed by three rinses with sterile deionized water, and stored at $-20^{\circ} \mathrm{C}$. The final rinse after sterilization was saved to verify sterility (Izumi et al., 2008).

\section{DNA EXTRACTION}

Needles were ground to a fine powder in a sterile mortar with liquid nitrogen. In a $2 \mathrm{ml}$ screw cap tube, $800 \mu \mathrm{l}$ of CTAB solution ( $1 \mathrm{ml}$ CTAB buffer, $0.04 \mathrm{~g}$ of polyvinylpyrollidone, $5 \mu \mathrm{l}$ of 2 -mercaptoethanol) was added to $0.6 \mathrm{~g}$ of ground needle material. The tube was then incubated in a dry bath at $60^{\circ} \mathrm{C}$ for $2 \mathrm{~h}$ with intermittent vortexing. After incubation, $0.3 \mathrm{~g}$ of $0.11 \mathrm{~mm}$ sterile glass beads was added to the tube and the sample was homogenized using a bead beater for $3 \mathrm{~min}$. To remove proteins, an equal amount of chloroform was added to the tube, vortexed, and centrifuged for $10 \mathrm{~min}$ at $16 \mathrm{rcf}$. For precipitation of nucleic acids, the aqueous top phase was placed in a sterile $2 \mathrm{ml}$ snap cap tube with $1 / 10$ volume of cold $3 \mathrm{M}$ sodium acetate and $1 / 2 \mathrm{vol}-$ ume cold isopropanol and placed in a $-20^{\circ} \mathrm{C}$ freezer for $12 \mathrm{~h}$. The sample was then centrifuged for $3 \mathrm{~min}$ at $16 \mathrm{rcf}$, supernatant decanted, $700 \mu \mathrm{l}$ of $70 \%$ ethanol added, and centrifuged for $10 \mathrm{~min}$. The air-dried pellet was resuspended with $30 \mu \mathrm{l}$ of DNA resuspension fluid (1.0 $\mathrm{M}$ Tris- $\mathrm{HCl}, 0.1 \mathrm{M}$ EDTA) and stored at $-20^{\circ} \mathrm{C}$.

\section{DNA AMPLIFICATION}

The extract was used to perform a nested PCR with Golay barcoded, chloroplast-excluding primers, 16S 799f (AACMGGATTAGATACCCKG) and 16S 1492r (TACGGHTACCTTGTTACGACTT; Chelius and Triplett, 2001; Redford et al., 2010), using the thermocycle profile described in Jiao etal. (2006). We used nested PCR to reduce the occurrence of plastid sequences, improve consistency (Hanshew et al., 2013) and minimize non-specific amplification from the barcoded primers that include 454 adapters (Berry et al., 2011). PCR amplification with primer $16 \mathrm{~S} 799 \mathrm{f}$ resulted in a mitochondrial product of about $1000 \mathrm{bp}$ and bacterial product of about $750 \mathrm{bp}$ as described in Chelius and Triplett (2001). The bacterial product was then separated and extracted using E-Gel ${ }^{\circledR}$ SizeSelect ${ }^{\mathrm{TM}}$ Gels (Life Technologies, Carlsbad, CA, USA). The extracted bacterial product was amplified with the thermocycle profile described by Jiao etal. (2006) using the barcoded primer set, 799f and 1115r (AGGGTTGCGCTCGTTG), described by Redford etal. (2010) as an optimized primer set for phylogenetic analysis of pyrosequencing reads. The final product was then cleaned, quantified using Nanodrop, and pooled for pyrosequencing. The pooled product was sent to the Environmental Genomics Core Facility at the University of South Carolina for pyrosequencing on a 454 Life Sciences Genome Sequencer FLX machine.

\section{SEOUENCE ANALYSIS}

Sequences were analyzed and processed using the QIIME package (Caporaso et al., 2010b). Briefly, sequences were quality filtered (minimum quality score of 25, minimum length of $200 \mathrm{bp}$, and no ambiguity in primer sequence) and assigned to their corresponding sample by the barcode sequences. Samples with less than 200 sequences were removed. These included three samples from a $P$. engelmannii WE1 individual, and one sample from one $P$. engelmannii WE2 individual. The remaining sequences were clustered into phylotypes using UCLUST (Edgar, 2010), with a minimum coverage of $99 \%$ and a minimum identity of 97\%. A representative sequence was chosen for each phylotype by selecting the longest sequence that had the highest number of hits to other sequences of that particular phylotype. Chimeric sequences were detected with ChimeraSlayer and removed before taxonomic analysis (Edgar et al., 2011). Representative sequences were aligned using PyNAST (Caporaso et al., 2010a) against the Greengenes core set (DeSantis et al., 2006). Taxonomic assignments were made using the Ribosomal Database Project (RDP) classifier (Wang et al., 2007). Sequences classified as "Chloroplast" $(0.2 \%)$ or "Mitochondria" $(8 \%)$ were removed from the alignment.

To compare diversity levels between WE and treeline samples and control for differences in sequencing depth between samples from the two environments, we conducted rarefaction analyses with 800 randomly selected sequences per sample. The rarefaction curves are displayed in Figure 1. The relative abundance of bacterial classes in each sample, displayed in Figure 2, was

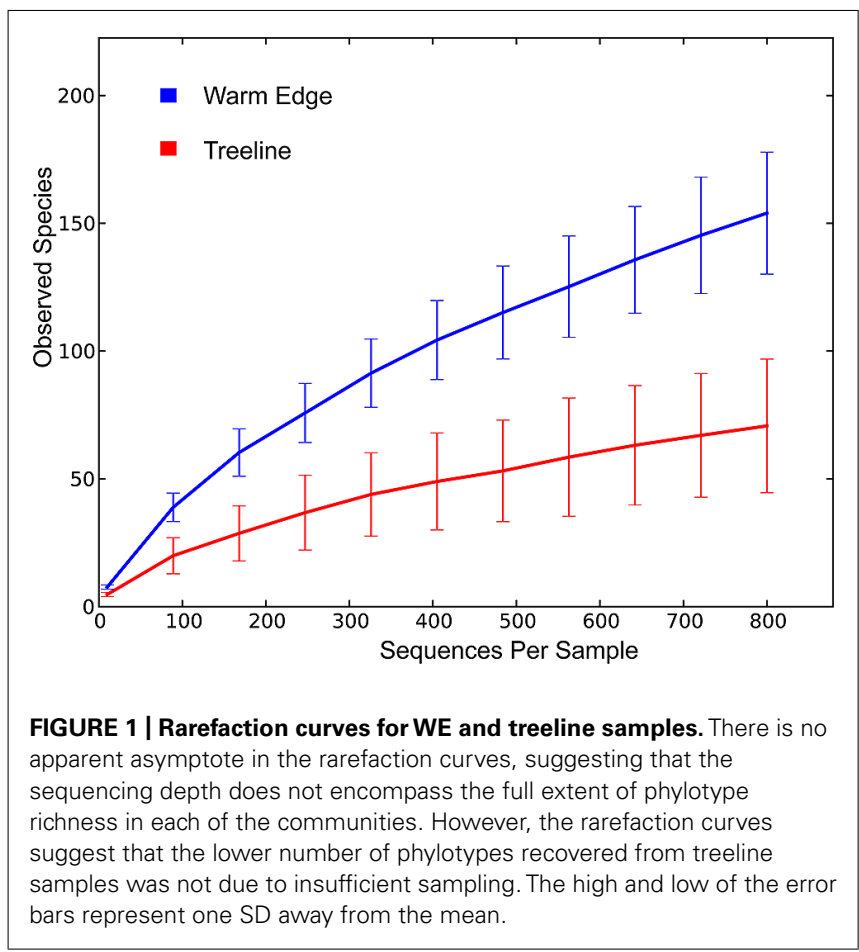




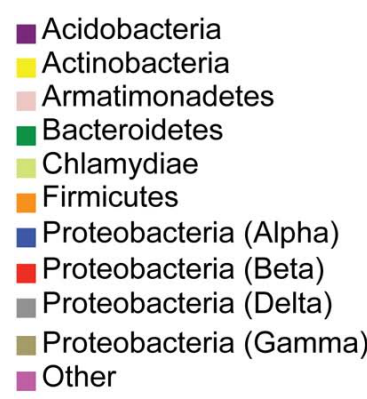

FIGURE 2 | Relative abundances of various major bacterial phyla and classes recovered from $\boldsymbol{P}$. flexilis and $\boldsymbol{P}$ engelmannii needles. Relative abundance of phyla (and classes of the Proteobacteria) was

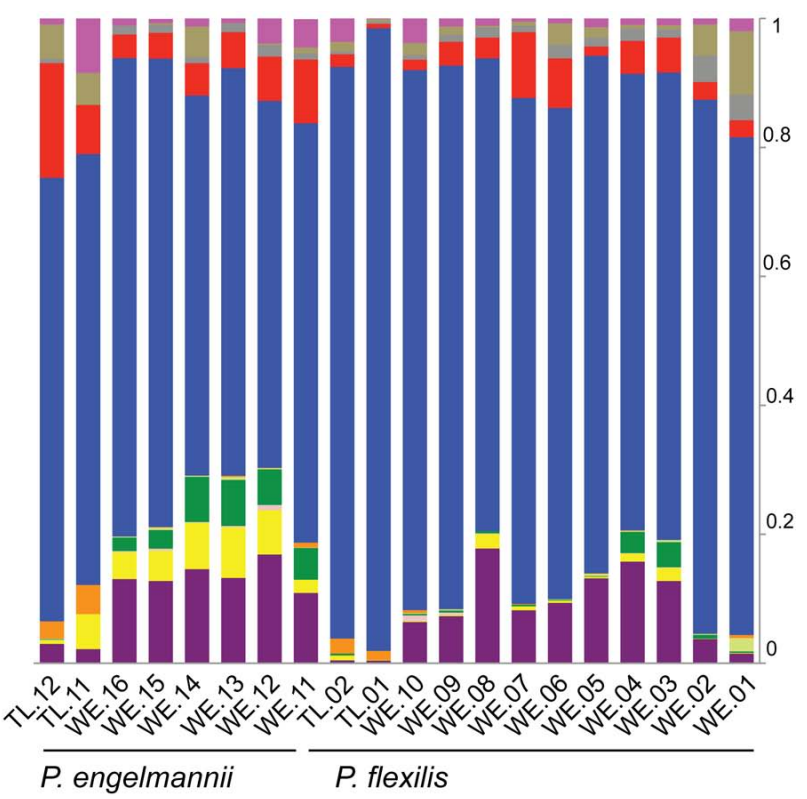

calculated as the percentage of sequences belonging to a particular lineage of all $16 \mathrm{~S}$ rRNA gene sequences recovered from each sample. calculated as the percentage of sequences belonging to a particular phylum of all 16S rRNA gene sequences recovered from each sample, with the Proteobacteria split into classes. The Alphaproteobacterial phylogenetic tree displayed in Figure 3 was created by first searching Alphaproteobacterial sequences that occurred at least 100 times in our data against the GenBank 16S rRNA database, using BLAST. The top hit for each sequence was then downloaded aligned from RDP. Our sequences, along with an outgroup sequence (Burkholderia arboris) were added to the alignment using ClustalW, before a maximum likelihood tree was inferred using RAxML (1000 bootstrap replicates; Stamatakis et al., 2005). To create the heatmap displayed in Figure 4, the heatmap function in QIIME was used. The function visualizes the operational taxonomic unit (OTU) table generated by QIIME (this table tabulates the number of times an OTU is found in each sample). In Figure 4, only the 10 most common OTUs (phylotypes) were included. To create Figure 5, a heatmap of all OTUs was generated to identify phylotypes unique to each species and shared across all samples, respectively. For each phylotype in Figures 4 and 5, the similarity to known isolates was determined though a BLAST search against the NCBI 16S rRNA database. To create Figure 6, an approximately maximum-likelihood tree was constructed from the alignment using FastTree (Price et al., 2009). An unweighted UniFrac distance matrix was constructed from the phylogenetic tree. The unweighted Unifraq distances were visualized using principal coordinate analysis (PCoA) and an UPGMA tree was created from the UniFraq distance matrix. Confidence ellipses (95\%) were drawn around groups on the PCoA plots using the ordiellipse function of the Vegan package in $\mathrm{R}$ (Oksanen etal., 2008).

\section{RESULTS}

\section{PHYLOTYPES RECOVERED FROM SAMPLES}

A total of 388 distinct bacterial phylotypes distributed across 166 bacterial phyla were recovered from 29,297 quality sequences from the 20 samples. These sequence data have been submitted to the GenBank databases under project accession No. SRP033097. On average, each sample yielded 1465 sequences after plant DNA was removed. The number of sequences recovered did not differ greatly between individuals, species, or locations (Table 1). The average number of phylotypes recovered also did not vary much within individuals or across species, but varied across locations. An average of 137 endophytic phylotypes were recovered from WE samples while an average of 53 phylotypes were recovered from treeline samples (Table 1). Rarefaction curves suggested that the lower number of phylotypes recovered from treeline samples was not due to insufficient sampling (Figure 1).

\section{DOMINANT BACTERIAL TAXA ASSOCIATED WITH $P$. flexilis AND $P$. engelmannii NEEDLES}

We found a low degree of intra-individual, inter-individual, and interspecies variability in the taxonomic structure of the endophytic communities of our two conifer species. The majority of detected taxa belonged to two bacterial phyla: Acidobacteria and Proteobacteria (Figure 2). The proportion of Acidobacteria varied among samples and accounted for between 2 and 17\% in the WE samples, but only $0.5-3 \%$ in the treeline samples. All of our samples were dominated by taxa in the Alphaproteobacteria (Figure 2). The Alphaproteobacterial phylotypes recovered here belong to five families: Acetobacteraceae, Beijerinckiaceae, Caulobacteraceae, Methylobacteriaceae, and Sphingomonadaceae. 


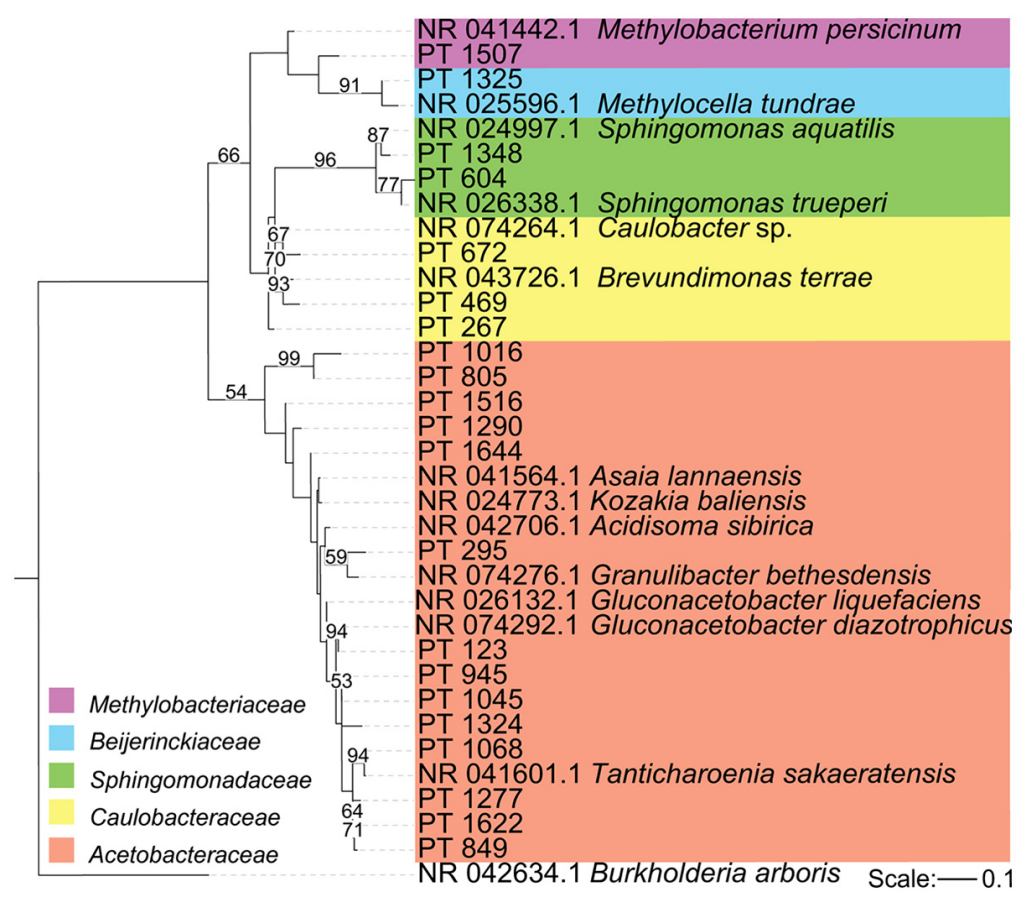

FIGURE 3 | Phylogeny of major Alphaproteobacterial sequences in our samples. Maximum likelihood phylogeny of Alphaproteobacterial sequences that occurred at least 100 times along with the three most closely related sequences from the GenBank $16 \mathrm{~S}$ rRNA database (accession number indicated). Because our sequences are short (approximately $300 \mathrm{nt}$ ), many of our clades have low bootstrap support. Here, only bootstrap values above $50 \%$ are displayed. The tree is rooted with Burkholderia arboris.
Among the Alphaproteobacteria, and over all, the Acetobacteraceae (acetic acid bacteria) was the most common family recovered in our samples. Eighty-eight out of the total 188 Alphaproteobacterial phylotypes detected belonged to this family, which dominated all samples, accounting for at least $60 \%$ of phylotypes detected in each sample. This family is currently classified into 13 genera; Acetobacter, Gluconobacter, Gluconacetobacter, Acidomonas, Asaia, Kozakia (Kersters et al., 2006), Swaminathania (Loganathan and Nair, 2004), Saccharibacter (Jojima et al., 2004), Neoasaia (Yukphan et al., 2005), Granulibacter (Greenberg et al., 2006), Commensalibacter (Roh et al., 2008), Tanticharoenia (Yukphan etal., 2008), and Ameyamaea (Yukphan etal., 2009). Figure 3 shows the phylogenetic relationship among the most common Alphaproteobacterial taxa in our samples, demonstrating a high diversity of Acetobacteraceae. However, the high predominance of Alphaproteobacteria and Acetobacteraceae at the class and family levels was driven by the consistent occurrence and high relative abundance of a few single phylotypes (Figures 4A,B). One single phylotype (1045), which is $97 \%$ similar to $G$. diazotrophicus, was the most common in all our samples. The exact phylogenetic placement of phylotype 1045 cannot be completely resolved with the $16 \mathrm{~S} \mathrm{~V}-5 / \mathrm{V}-6$ region used in this study (Figure 3), and may represent a novel species in the genus Gluconacetobacter or a related genus within the Acetobacteraceae.

The relative abundance and identity of the rest of the dominant endophytic taxa differed somewhat between the two conifer species, although there was also substantial overlap. The most prominent difference was seen between WE and treeline individuals, rather than between the two conifer species, although our small sample size of treeline trees (two trees of each species) prohibits us from drawing any conclusions based on these. Overall, the community of dominant taxa in P. flexilis was less diverse; in addition to 1045 only one more phylotype (1516) was consistently present above $10 \%$ in the WE samples, and another (1068) consistently present above 4\% (Figure 4A). Both phylotypes 1516 and 1068 belong to the Acetobacteraceae. Phylotype 1516 is 95\% similar to Gluconacetobacter liquefaciens, and phylotype 1068 is $98 \%$ similar to Tanticharoenia sakaeratensis. The rest of the 10 most abundant phylotypes in $P$. flexilis WE samples were present at much lower relative abundance (Figure 4A). An analysis of all phylotypes in all samples ensured that no individual sample was dominated by a phylotype other than the 10 most abundant in each tree species (data not shown).

The two conifer species shared five of their 10 most dominant phytotypes (Figures 4A,B). P. engelmannii WE samples had a slightly more diverse community of dominant phylotypes, with more phylotypes present above $4 \%$, and with more variation in dominant phylotypes within and among individuals. Like $P$. flexilis, P. engelmannii had a high relative abundance of phylotype 1516 (5-16\%). P. engelmannii trees at WE sites were also dominated by phylotypes not found in abundance in treeline P. engelmannii or P. flexilis samples; phylotype 1507 is a Methylobacterium species; 1295 is 95\% similar to Terriglobus roseus in the family Acidobacteria; and 1324 is $95 \%$ similar to Kozakia balinesis, another species in the family Acetobacteraceae (Figure 4B). 
A

\begin{tabular}{|c|c|c|c|c|c|c|c|c|c|c|c|c|c|c|c|c|}
\hline $\begin{array}{l}\bar{\delta} \\
\text { ய் }\end{array}$ & 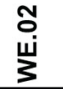 & $\begin{array}{l}\text { \% } \\
\text { ய் } \\
3\end{array}$ & $\begin{array}{l}\text { す } \\
\text { ய } \\
3\end{array}$ & $\begin{array}{l}\text { ن } \\
\text { س } \\
3\end{array}$ & $\begin{array}{l}\mathscr{8} \\
\text { ய் } \\
3\end{array}$ & $\begin{array}{l}\hat{\delta} \\
\text { ய } \\
3\end{array}$ & $\begin{array}{l}\infty \\
0 \\
\text { ய } \\
3\end{array}$ & $\begin{array}{l}\text { ஜ } \\
\text { ய் }\end{array}$ & $\begin{array}{l}\stackrel{0}{\text { ن }} \\
\frac{1}{3}\end{array}$ & $\begin{array}{l}\overline{0} \\
\dot{1}\end{array}$ & $\begin{array}{c}\mathfrak{N} \\
\stackrel{j}{F}\end{array}$ & PT & GenBank\# & $\begin{array}{l}\% \\
\text { ID }\end{array}$ & Match & Phylum/class/family \\
\hline 3.3 & 2.7 & 2.4 & 2.1 & 3.5 & 3.0 & 2.7 & 2.1 & 2.7 & 4.0 & 0.0 & 0.0 & 123 & NR_074284.1 & 98 & Gluconacetobacter diazotrophicus & Proto/Alpha/Acetobac \\
\hline 1.4 & 1.4 & 2.0 & 2.2 & 0.4 & 3.7 & 4.7 & 1.6 & 1.7 & 0.1 & 0.6 & 0.5 & 816 & NR_042813.1 & 99 & Pandoraea pnomenusa & Proto/Beta/Burkhold \\
\hline 3.2 & 2.0 & 1.7 & 0.7 & 1.5 & 1.0 & 1.1 & 1.2 & 2.1 & 1.5 & 0.0 & 0.0 & 849 & NR_024959.1 & 95 & Gluconacetobacter johannae & Proto/Alpha/Acetobac \\
\hline 1.9 & 0.7 & 0.4 & 0.7 & 0.6 & 1.2 & 1.1 & 0.4 & 0.7 & 0.3 & 8.4 & 7.7 & 1016 & NR_024773.1 & 96 & Kozakia baliensis & Proto/Alpha/Acetobac \\
\hline 36.0 & 34.4 & 22.5 & 19.1 & 30.1 & 33.5 & 30.5 & 23.4 & 29.5 & 24.1 & 53.2 & 48.9 & 1045 & NR_074292.1 & 97 & Gluconacetobacter diazotrophicus & Proto/Alpha/Acetobac \\
\hline 7.4 & 6.3 & 5.5 & 3.5 & 5.6 & 4.0 & 3.2 & 5.6 & 4.2 & 4.0 & 0.2 & 0.2 & 1068 & NR_041601.1 & 98 & Tanticharoenia sakaeratensis & Proto/Alpha/Acetobac \\
\hline 0.9 & 1.2 & 2.7 & 4.0 & 3.1 & 2.5 & 1.2 & 3.8 & 1.1 & 1.6 & 0.0 & 0.1 & 1257 & NR_074294.1 & 95 & Terriglobus saanensis & Proto/Acidobac/Acidobac \\
\hline 0.3 & 0.6 & 2.6 & 2.2 & 1.6 & 0.8 & 1.6 & 2.1 & 2.5 & 3.5 & 0.0 & 0.0 & 1507 & NR_041442.1 & 93 & Methylobacterium persicinum & Proto/Alpha/Methylobac \\
\hline 10.0 & 16.5 & 11.0 & 11.2 & 9.3 & 11.5 & 11.9 & 7.9 & 17.5 & 22.1 & 2.8 & 2.7 & 1516 & NR_026132.1 & 95 & Gluconacetobacter liquefaciens & Proto/Alpha/Acetobac \\
\hline 0.3 & 0.5 & 0.4 & 0.5 & 1.4 & 0.7 & 0.5 & 1.1 & 0.7 & 0.5 & 26.9 & 24.3 & 1644 & NR_041564.1 & 97 & Asaia lannaensis & Proto/Alpha/Acetobac \\
\hline
\end{tabular}

B

\begin{tabular}{|c|c|c|c|c|c|c|c|c|c|c|c|c|}
\hline 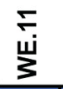 & $\underset{⿱}{\stackrel{N}{3}}$ & $\stackrel{m}{\stackrel{m}{3}}$ & $\underset{⿱ 亠 䒑}{ \pm}$ & $\frac{\text { n }}{3}$ & $\underset{⿱ ㇒}{\stackrel{0}{3}}$ & $\underset{F}{F}$ & $\underset{\sim}{\stackrel{F}{F}}$ & PT & GenBank\# & $\begin{array}{l}\% \\
\text { ID }\end{array}$ & Match & Phylum/class/order \\
\hline 3.8 & 4.9 & 2.2 & 2.1 & 1.5 & 2.0 & 0.0 & 0.0 & 29 & NR_074294.1 & 93 & Terriglobus saanensis & Proto/Acidobac/Acidobac \\
\hline 4.3 & 5.0 & 3.0 & 4.4 & 1.4 & 0.8 & 0.0 & 0.1 & 603 & NR_029359.1 & 96 & Hymenobacter roseosalivarius & Proto/Bacteroid/Cytophag \\
\hline 2.3 & 3.3 & 2.5 & 2.5 & 2.4 & 2.4 & 0.0 & 0.3 & 604 & NR_026338.1 & 98 & Sphingomonas trueperi & Proto/Alpha/Sphingomonad \\
\hline 1.7 & 2.3 & 1.3 & 0.9 & 0.7 & 0.9 & 4.6 & 13.1 & 816 & NR_042813.1 & 99 & Pandoraea pnomenusa & Proto/Beta/Burkhold \\
\hline 15.6 & 18.7 & 14.7 & 14.1 & 18.2 & 17.5 & 37.5 & 39.0 & 1045 & NR_074292.1 & 97 & Gluconacetobacter diazotrophicus & Proto/Alpha/Acetobac \\
\hline 2.5 & 8.5 & 4.9 & 5.1 & 4.6 & 4.4 & 0.1 & 0.7 & 1295 & NR_043918.1 & 98 & Terriglobus roseus & Proto/Acidobac/Acidobac \\
\hline 2.2 & 3.7 & 3.5 & 3.5 & 4.7 & 5.3 & 0.1 & 0.0 & 1324 & NR_024773.1 & 95 & Kozakia baliensis & Proto/Acidobac/Acetobac \\
\hline . & 9.7 & 9.5 & 7.7 & 6.7 & 5.1 & 0.0 & 0.2 & 1507 & NR_041442.1 & 93 & Methylobacterium persicinum & Proto/Alpha/Methylobac \\
\hline 11.0 & 16.2 & 5.4 & 6.4 & 5.6 & 5.2 & 2.9 & 1.5 & 1516 & NR_026132.1 & 95 & Gluconacetobacter liquefaciens & Proto/Alpha/Acetobac \\
\hline 0.2 & 0.7 & 0.4 & 0.2 & 0.6 & 0.7 & 18.6 & 1.7 & 1644 & NR_041564.1 & 97 & Asaia lannaensis & Proto/Alpha/Acetobac \\
\hline
\end{tabular}

FIGURE 4 | Heatmap showing the 10 most dominant phylotypes and their average relative abundances as percentages of all sample $16 \mathrm{~S}$ rRNA gene sequences recovered in our conifer needles samples.

(A) P. flexilis, (B) P. engelmannii. Color tones range from cool (blue) to warm (red) to indicate the lowest to highest relative abundance values.

Phylotypes were considered dominant if they were both highly abundant and occurred frequently in samples of a given conifer species.

Abbreviations: PT = Phylotype, Acetobac = Acetobacteraceae, Acidobac $=$ Acidobacteria/Acidobacteriaceae, Burkhold = Burkholderiaceae, Bacteriod = Bacteriodetes, Flexibacteraceae, Methylobac = Methylobacteriaceae, Cytophag $=$ Cytophagacae, Sphingomonad $=$ Sphingomonadaceae.
Phylotypes shared across all individuals in one conifer species but not found in the other conifer species were rare (Figure 5). Only a limited subset of the needle endophytic microbiota appeared to be host species-specific; instead the differences in endophytic community composition between the two hosts were due to different relative abundances of a set of shared dominant phylotypes. The relative abundance of phylotype 1045 was highest in trees growing at treeline, making up 53 and $49 \%$ of the sequences in the $P$. flexilis treeline individuals, and 38 and $39 \%$ of the sequences in the $P$. engelmannii treeline individuals (Figures 4A,B). In the two $P$. flexilis treeline individuals, phylotype 1644 , which is $97 \%$ similar to Asaia lannaensis (also in the Acetobacteraceae family), was the second most common after phylotype 1045. One $P$. engelmannii individual at treeline also had an increased relative abundance of phylotype 1644 . The other $P$. engelmannii treeline individual had an increased relative abundance of a different phylotype-816, which is $99 \%$ similar to Pandoraea pnomenusa in the Burkolderiales family.

\section{STRUCTURE OF CONIFER NEEDLE ENDOPHYTE COMMUNITIES}

Principal coordinate analysis of the unweighted UniFraq diversity distance matrix demonstrated that within the WE habitat, host species identity controls endophyte community composition (Figure 6). P. flexilis samples from the two WE locations clustered to the exclusion of $P$. engelmannii samples from the same locations. Conifer needle endophyte community structure may also be a function of elevation, as the endophyte communities from our treeline samples clustered together to the exclusion of communities from WE samples. However, endophytic communities from more treeline samples will need to be characterized to confirm this observation.

\section{DISCUSSION}

Our results demonstrate that $P$. flexilis and $P$. engelmannii growing at Niwot Ridge are consistently colonized by a limited set of bacterial species belonging to the Alphaproteobacteria and the Acidobacteria, and that the two species share some of the 
most dominant phylotypes. Most remarkably, all needle samples of both conifer species were dominated by the same phylotype, a species most closely related to the $\mathrm{N}_{2}$ fixing species $G$. diazotrophicus. However, is important to point out that $97 \%$ similarity over the V-5/V-6 region is not sufficient to identify a particular species. The primer pair used in this study have been used with other plants without resulting in a similar dominance across samples of one phylotype (Bodenhausen et al., 2013, Carrell and Frank, unpublished). Therefore, the patterns observed here are not likely to be caused by primer bias. It is also possible that specific taxa could be selected by our treatment (e.g.,

\begin{tabular}{|c|c|c|}
\hline Phylotype & Match & $\%$ identity \\
\hline 123 & Gluconacetobacter diazotrophicus & $98^{*}$ \\
\hline 267 & Caulobacter sp. & 97 \\
\hline 295 & Acidisphaera rubrifaciens & 95 \\
\hline 333 & Granulicella tundricola & 98 \\
\hline 663 & Terriglobus roseus & 99 \\
\hline 669 & Roseatele terrae & 98 \\
\hline 805 & Tanticharoenia sakaeratensis & 93 \\
\hline 816 & Pandoraea pnomenusa & $99^{*}$ \\
\hline 1016 & Kozakia baliensis & $96^{*}$ \\
\hline 1045 & Gluconacetobacter diazotrophicus & $97^{*}$ \\
\hline 1067 & Terriglobus saanensis & 97 \\
\hline 1068 & Tanticharoenia sakaeratensis & $98^{*}$ \\
\hline 1290 & Tanticharoenia sakaeratensis & 95 \\
\hline 1295 & Terriglobus roseus & $98^{*}$ \\
\hline 1433 & Geobacter metallireducens & 89 \\
\hline 1516 & Gluconacetobacter liquefaciens & $95^{*}$ \\
\hline 1644 & Asaia lannaensis & $97^{*}$ \\
\hline 1813 & Herbaspirillum rhizosphaerae & 99 \\
\hline \multicolumn{3}{|c|}{$\begin{array}{l}\text { FIGURE } \mathbf{5} \text { I Shared and host species-specific phylotypes. Blue: } \\
\text { phylotypes found in all P. engelmannii samples but not in any of the } P \text {. } \\
\text { flexilis samples. Red: phylotypes found in all } P \text {. flexilis samples but not in } \\
\text { any of the } P \text {. engelmannii samples. Purple: indicates phylotypes recovered } \\
\text { from all samples (i.e., both species). An asterisk indicates that the } \\
\text { phylotype is included in Figure 2. }\end{array}$} \\
\hline
\end{tabular}

transportation in plastic bags at $4^{\circ} \mathrm{C}$ ). However, this is unlikely since endophyte communities of other conifer tissues and species treated the same way are not consistently dominated by a few taxa (Carrell and Frank, unpublished). In addition, we find the same pattern in needles of $P$. contorta where the time from sampling to sterilization was less then $2 \mathrm{~h}$ (Carrell and Frank, unpublished).

Bacterial species that are consistently recovered from a certain host species are predicted to be critical to the function of the microbial community (Shade and Handelsman, 2012). For host-associated communities, this may translate into distinct functional roles for those species within the host. However, abiotic factors could also shape host-associated bacterial communities, contributing to consistency in microbiota across samples if the environment is consistent. The dominance of Acidobacteria and Alphaproteobacteria in all our samples probably reflects the ability of these bacteria to survive the conditions within conifer needles. In addition, functionally relevant conifer-bacteria partnerships could underlie their dominance in the endophytic community.

The relative abundance of specific phylotypes from the Acidobacteria was low and their presence was not consistent across samples. Given that Acidobacteria have been found to dominate the alpine dry meadow site soils at Niwot Ridge (Lipson and Schmidt, 2004), their overall prevalence might reflect their ability to tolerate the needle environment and their abundance in the soil rather than a functional relationship with the conifer host. Alphaproteobacteria are also common in the soil at Niwot Ridge (Lipson and Schmidt, 2004); however, in contrast to the Acidobacteria, the dominance of Alphaproteobacteria in all our samples was driven by a few specific phylotypes from the Acetobacteraceae (e.g., 1045, 1516, and 1644 in P. flexilis, and 1045, 1516,1324 , and 1644 in P. engelmannii), suggesting that in addition to tolerating the needle environment, those bacterial taxa serve distinct functional roles within the needles of our subalpine conifers. An association based merely on the ability to survive the environment inside pine needles would more likely result in

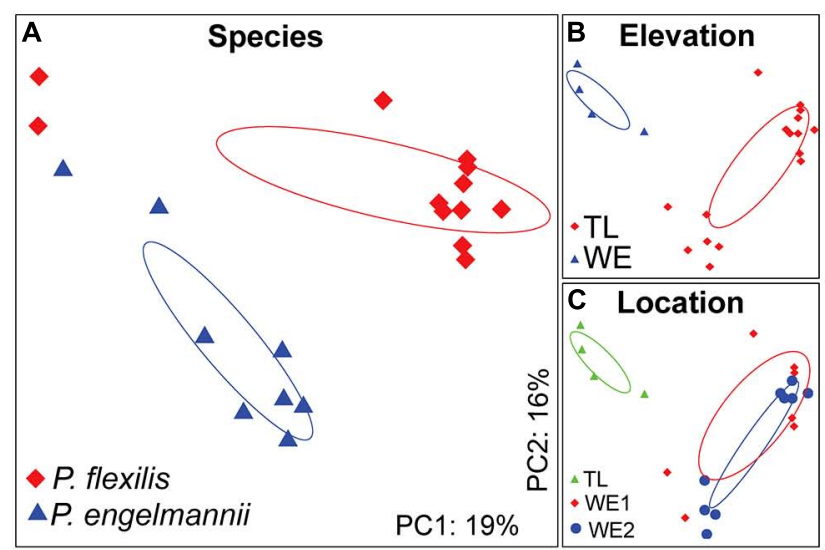

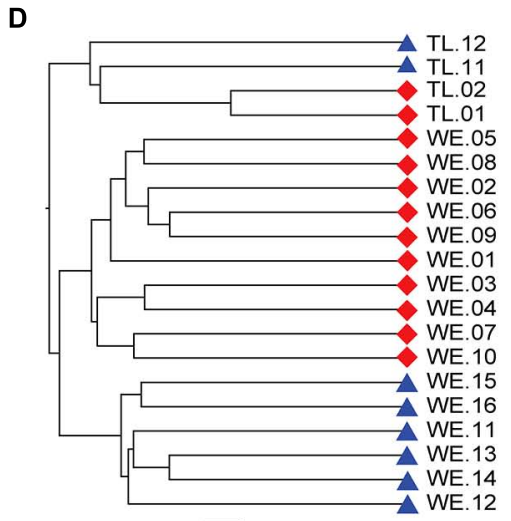

$\overline{0.04}$
FIGURE 6 | PCoA and UniFrac analysis of the bacterial communities associated with conifer needles. (A-C) PCOA of the unweighted UniFrac distance matrix. Points that are closer together on the ordination have communities that are more similar. Each point corresponds to a sample, and shapes correspond to (A) host species, (B) elevation, and (C) location. (D) Hierarchical clustering of composite communities of the conifer species. Leaves are labeled by color according to host species: red, P. flexilis; blue, P. engelmannii. 
a variable (within and among individuals) community of taxa in the Acetobacteraceae.

Several high-throughput surveys of endophytic 16SrRNA have been published recently, but no study to date has reported a similarly simple and consistent endophyte microbiota. A study of the Populus deltiodes root endophyte community reported that a Pseudomonas phylotype accounted for $34 \%$ of bacterial sequences in all samples combined; however, the extent to which this phylotype was consistently associated with individual trees was not reported (Gottel et al., 2011). Similarly, a study of the leaf endoand epiphytes of Arabidopsis thaliana found a high relative abundance of a single Pseudomonas phylotype at $10.9 \%$ on average in the endophyte community (Bodenhausen et al., 2013), but interindividual variability in the relative abundance of phylotypes was not studied. Finally, two recent large-scale studies of $A$. thaliana root endophytes did not report consistent dominance of one or a few phylotypes (Bulgarelli et al., 2012; Lundberg et al., 2012), and comparison across $A$. thaliana root microbiomes did not reveal a common core at the phylotype level (Schlaeppi et al., 2014).

It is important to point out that the phylotypes with the highest number of sequences are not necessarily the most abundant in the community. One potential source of bias is the primer used in this study (799f), which was designed to exclude chloroplast sequences, but likely excludes other sequences as well (e.g., the Cyanobacteria). However, because this primer has been used with very different results in terms of community diversity, variability and taxonomic distribution (Bodenhausen et al., 2013; Schlaeppi et al., 2014), it unlikely underlies the community consistency observed here.

The high relative abundance of a few phylotypes across individuals, host species and elevations may be due to ecologically significant associations between conifers and specific bacteria in the family Acetobacteraceae. Species in this family are often found as endophytes, with documented functions in $\mathrm{N}$ fixation (Boddey etal., 2003), phytohormone production (Lee et al., 2004), and pathogen antagonism (Blanco et al., 2005). Acetobacteraceae are also common symbionts of insects (Crotti etal., 2010). A number of strains from the family are known to solubilize phosphate (P; Loganathan and Nair, 2004). Although $\mathrm{P}$ solubilizing endophytes can increase plant uptake of P (Verma etal., 2001; Wakelin et al., 2004), this is not a likely function of above-ground endophytes. Therefore, $\mathrm{N}_{2}$ fixation, pathogen protection, or phytohormone production is more likely to underlie the high relative abundance of Acetobacteraceae inside P. flexilis and P. engelmannii needles. G. diazotrophicus, Gluconacetobacter johannae, Gluconacetobacter azotocaptans, Swaminathania salitolerans, and Acetobacter peroxydans all fix $\mathrm{N}_{2}$ in association with plants (Gillis et al., 1989; Fuentes-Ramirez et al., 2001; Loganathan and Nair, 2004; Muthukumarasamy et al., 2005), and Gluconacetobacter kombuchae and Acetobacter nitrogenifigens, are free-living $\mathrm{N}_{2}$ fixers (Dutta and Gachhui, 2006, 2007). Among $\mathrm{N}_{2}$ fixing endophytes in the Acetobacteraceae, G. diazotrophicus is probably the best studied. This species colonizes the intercellular spaces of sugarcane stems (Dong et al., 1994), and may, together with other diazotrophic endophytes of sugarcane, provide the host plant with substantial amounts of N (Boddey, 1995). G. diazotrophicus has also been found to dominate $\mathrm{N}_{2}$ fixation "hotspots" in soil (Reed et al., 2010).

Fertilization experiments in the subalpine forest in Colorado have suggested that this habitat is still $\mathrm{N}$ limited, despite increasing $\mathrm{N}$ deposition (Rueth and Baron, 2002), raising the possibility that this partnership involves endophytic $\mathrm{N}_{2}$ fixation. More research is needed to evaluate the role of phylotype 1045 in our conifer species; however, evaluation of biological $\mathrm{N}_{2}$ fixation associated with non-legumes can be challenging (Boddey, 1995). Phylotype 1045 may not be a culturable strain as our initial attempts to culture any Acetobacteraceae from needles have been unsuccessful (Wilson and Frank, unpublished). $\mathrm{N}_{2}$-fixing potential and expression of nitrogenase in, e.g., soil and ocean water is commonly estimated via amplification of nifH with degenerate primers (Farnelid et al., 2013; Collavino et al., 2014). Unfortunately, although a few studies report amplification of nifH (nitrogenase) from DNA extracted from plants (e.g., sugarcane, sweet potato and rice roots; Ueda et al., 1995; Reiter et al., 2003; Ando et al., 2005), this has proven challenging in our system.

The idea that conifers form associations with $\mathrm{N}_{2}$-fixing bacteria is not new. Early attempts to estimate rates of $\mathrm{N}_{2}$ fixation in temperate and boreal forests detected significant amounts of atmospherically derived $\mathrm{N}$ in the conifer canopy (Richards, 1964; Jones et al., 1974; Favilli and Messini, 1990). Moreover, natural abundance studies that exploit naturally occurring differences in ${ }^{15} \mathrm{~N}$ composition between plant-available $\mathrm{N}$ sources in the soil and that of atmospheric $\mathrm{N}_{2}$, have shown that the Pinaceae, which presumably do not fix appreciable amounts of $\mathrm{N}_{2}$, run counter to the expectation of high ${ }^{15} \mathrm{~N}$ abundance and low foliar content for non- $\mathrm{N}_{2}$ fixing plants (Delwiche et al., 1979; Virginia and Delwiche, 1982; Näsholm et al., 2009).

Endophytic $\mathrm{N}_{2}$ fixation could explain why some gymnosperms are able to grow in extremely $\mathrm{N}$ limited environments (Anand et al., 2013). It is generally presumed that conifers and other nonnodulated plants get their $\mathrm{N}$ from the soil. Conifer uptake of amino acids and proteins has been demonstrated but its quantitative importance is still under debate (Näsholm et al., 2009). Rhizospheric $\mathrm{N}_{2}$ fixation has been suggested as a conifer $\mathrm{N}$ source, but the activity has been found too low to support $\mathrm{N}$ requirement, at least in pines (Chanway and Holl, 1991). Ectomychorrhizae are another suggested N source (Hobbie et al., 2000; Chapman and Paul, 2012), but work on non-mycorrhizal conifer seedlings provides strong support for endophytic $\mathrm{N}_{2}$ fixation as an alternative explanation: Conifer seedlings inoculated with $\mathrm{N}_{2}$ fixing Paenibacillus strain isolated from $P$. contorta growing in $\mathrm{N}$ limited soil (Bal et al., 2012) have been found to acquire significant amounts of seedling foliar $\mathrm{N}$ from the atmosphere compared to control seedlings (Bal and Chanway, 2012; Anand and Chanway, 2013).

In light of this, it is striking that several potentially $\mathrm{N}_{2}$ fixing taxa dominate the community of needle-associated endophytes of conifers growing in the $\mathrm{N}$ limited subalpine environment at Niwot Ridge. Phylotype 1045, which is $97 \%$ similar to G. diazotrophicus, and the most common in every single sample, is the main candidate for an $\mathrm{N}_{2}$ fixing symbiosis in $P$. flexilis and $P$. engelmannii at this location. Interestingly, we found that phylotype 1045 was present in higher relative abundance in P. flexilis, 
which is found on drier and likely lower $\mathrm{N}$ soils than $P$. engelmannii, which is found on more mesic and potentially higher $\mathrm{N}$ soils. We also found that in both conifer species, the relative abundance of this phylotype was higher in trees growing at treeline than in trees growing at the WE, which could reflect slower $\mathrm{N}$ turnover at treeline or higher $\mathrm{N}$ demands by treeline trees. However, total abundance of phylotype 1045 may not differ among WE and treeline trees; it may simply be a function of overall lower diversity in treeline environments. More endophyte community data from the treeline environment will be required to establish links between the conifer endophyte community structure and elevation.

A consistent core microbiota similar to the one observed here would be promoted by selective uptake/transfer of bacteria. Not much is known with regards to the transmission of bacterial endophytes in conifer trees, but possible routes include soil, litter, seed and stomata. Given the long lifetime of $P$. flexilis and $P$. engelmannii, as well as needle longevity (e.g., 4-10 years for P. flexilis; Schoettle and Rochelle, 2000), the time spent within individual hosts is expected to be longer than for most hostmicrobe associations, possibly leading to convergence in the endophyte community assembly among different individuals. The consistency in the endophytic community between the two host species is intriguing. This pattern could reflect a strong local and environmental influence on endophyte uptake, leading to a shared endophyte community between co-occurring species in a shared habitat. Alternatively, the selective uptake/transfer of specific strains of Acetobacteraceae could be an ancestral trait that is shared between Pinus and Picea species, which together with Cathaya form a clade in the Pinaceae phylogeny (Lin et al., 2010). If so, the dominance of phylotype 1045 in both host species may be the result of a long-standing association with possible co-diversification of host and endophyte. Our current sequences-approximately 300 nucleotides across over the V5/V-6 region-do not provide enough resolution to evaluate possible divergence between strains represented by phylotype 1045 from the two conifer species. To understand why P. flexilis and $P$. engelmannii at Niwot Ridge have such similar endophyte communities, further research is needed that includes a broader range of conifer species, habitats, and geographic locations, along with the amplification of longer segments of the 16S rRNA gene.

This first comprehensive analysis of the bacterial endophyte communities in a gymnosperm provides circumstantial evidence for endophytic $\mathrm{N}_{2}$ fixation in subalpine conifers growing in an $\mathrm{N}$ limited environment. Demonstration of a role of conifer endophytes in host $\mathrm{N}$ acquisition, along with the extent and potential significance in the conifer forest $\mathrm{N}$ budget will require direct tests for endophytic $\mathrm{N}_{2}$ fixation and $\mathrm{N}$ transfer to the conifer host.

\section{AUTHOR CONTRIBUTIONS}

Alyssa A. Carrell and Anna C. Frank conceived and designed the sampling and experiments. Alyssa A. Carrell designed the primers, performed the DNA extraction, PCR amplification, and the data analysis. Anna C. Frank contributed intellectually to data analysis. Alyssa A. Carrell drafted the work; Anna C. Frank revised it critically for important intellectual content.

\section{ACKNOWLEDGMENTS}

We thank Michele Conrad for performing the sampling, and Lara Kueppers for giving constructive comments on the manuscript. This work was supported by UC Merced startup funds.

\section{REFERENCES}

Anand, R., and Chanway, C. P. (2013). $\mathrm{N}_{2}$-fixation and growth promotion in cedar colonized by an endophytic strain of Paenibacillus polymyxa. Biol. Fertil. Soils 49, 235-239. doi: 10.1007/s00374-012-0735-9

Anand, R., Grayston, S., and Chanway, C. (2013). N2-fixation and seedling growth promotion of lodgepole pine by endophytic Paenibacillus polymyxa. Microb. Ecol. 66, 369-374. doi: 10.1007/s00248-013-0196-1

Ando, S., Goto, M., Meunchang, S., Thongra-ar, P., Fujiwara, T., Hayashi, H., et al. (2005). Detection of nifH squences in sugarcane (Saccharurnomcinarurn L.) and Pineapple (Ananas cornosus [L.] Merr.). Soil Sci. Plant Nutr. 51, 303-308. doi: 10.1111/j.1747-0765.2005.tb00034.x

Arnold, A. E., Mejia, L. C., Kyllo, D., Rojas, E. I., Maynard, Z., Robbins, N., et al. (2003). Fungal endophytes limit pathogen damage in a tropical tree. Proc. Natl. Acad. Sci. U.S.A. 100, 15649-15654. doi: 10.1073/pnas.2533483100

Arshad, M., and Frankenberger, W. T. (1991). Microbial production of plant hormones. Plant Soil 133, 1-8. doi: 10.1007/BF00011893

Bal, A., Anand, R., Berge, O., and Chanway, C. P. (2012). Isolation and identification of diazotrophic bacteria from internal tissues of Pinus contorta and Thuja plicata. Can. J. For. Res. 42, 807-813. doi: 10.1139/x2012-023

Bal, A., and Chanway, C. P. (2012). Evidence of nitrogen fixation in lodgepole pine inoculated with diazotrophic Paenibacillus polymyxa. Botany 90, 891-896. doi: 10.1139/b2012-044

Berry, D., Ben Mahfoudh, K., Wagner, M., and Loy, A. (2011). Barcoded primers used in multiplex amplicon pyrosequencing bias amplification. Appl. Environ. Microbiol. 77, 7846-7849. doi: 10.1128/AEM.05220-11

Binkley, D., Yowhan, S., and Valentine, D. W. (2000). Do forests receive occult inputs of nitrogen? Ecosystems 3, 321-331. doi: 10.1007/s100210000029

Blanco, Y., Blanch, M., Pinon, D., Legaz, M. E., and Vicente, C. (2005). Antagonism of Gluconacetobacter diazotrophicus (a sugarcane endosymbiont) against Xanthomonas albilineans (pathogen) studied in alginate-immobilized sugarcane stalk tissues. J. Biosci. Bioeng. 99, 366-371. doi: 10.1263/jbb.99.366

Boddey, R. M. (1995). Biological nitrogen fixation in sugar cane: a key to energetically viable biofuel production. Crit. Rev. Plant Sci. 14, 263-279. doi: 10.1080/07352689509701929

Boddey, R. M., Urquiaga, S., and Reis, V. M. (2003). Endophytic nitrogen fixation in sugarcane: present knowledge and future applications. Plant Soil 252, 139-149. doi: $10.1023 / \mathrm{A}: 1024152126541$

Bodenhausen, N., Horton, M. W., and Bergelson, J. (2013). Bacterial communities associated with the leaves and the roots of Arabidopsis thaliana. PLoS ONE 8:e56329. doi: 10.1371/journal.pone.0056329

Bormann, B. T., Bormann, H., Bowden, W. B., Piece, R. S., Hamburg, S. P., Wang, D., et al. (1993). Rapid $N_{2}$ fixation in pines, alder, and locust: evidence from the Sandbox Ecosystems study. Ecosystems 74, 583-598.

Bormann, B. T., Keller, C. K., Wang, D., and Bormann, H. (2002). Lessons from the Sandbox: is unexplained nitrogen real? Ecosystems 5, 727-733. doi: 10.1007/s10021-002-0189-2

Bulgarelli, D., Rott, M., Schlaeppi, K., Ver Loren van Themaat, E., Ahmadinejad, N., Assenza, F., etal. (2012). Revealing structure and assembly cues for Arabidopsis root-inhabiting bacterial microbiota. Nature 488, 91-95. doi: 10.1038/nature11336

Cankar, K., Kraigher, H., Ravnikar, M., and Rupnik, M. (2005). Bacterial endophytes from seeds of Norway spruce (Picea abies L. Karst). FEMS Microbiol. Lett. 244, 341-345. doi: 10.1016/j.femsle.2005.02.008

Caporaso, J. G., Bittinger, K., Bushman, F. D., DeSantis, T. Z., Andersen, G. L., and Knight, R. (2010a). PyNAST: a flexible tool for aligning sequences to a template alignment. Bioinformatics 26, 266-267. doi: 10.1093/bioinformatics/btp636

Caporaso, J. G., Kuczynski, J., Stombaugh, J., Bittinger, K., Bushman, F. D., Costello, E. K., et al. (2010b). QIIME allows analysis of high-throughput community sequencing data. Nat. Methods 7, 335-336. doi: 10.1038/nmeth.f.303

Carroll, G. (1988). Fungal endophytes in stems and leaves: from latent pathogen to mutualistic symbiont. Ecology 69, 2-9. doi: 10.2307/1943154

Chanway, C., and Holl, F. B. (1991). Biomass increase and associative nitrogen fixation of mycorrhizal Pinus contorta seedlings inoculated with a plant 
growth promoting Bacillus strain. Can. J. Bot. 69, 507-511. doi: 10.1139/ b91-069

Chapman, W. K., and Paul, L. (2012). Evidence that northern pioneering pines with tuberculate mycorrhizae are unaffected by varying soil nitrogen levels. Microb. Ecol. 64, 964-972. doi: 10.1007/s00248-012-0076-0

Chelius, M. K., and Triplett, E. W. (2001). The diversity of archaea and bacteria in association with the roots of Zea mays L. Microb. Ecol. 41, 252-263.

Collavino, M. M., Tripp, H. J., Frank, I. E., Vidoz, M. L., Calderoli, P. A., Donato, M., et al. (2014). nifH pyrosequencing reveals the potential for location-specific soil chemistry to influence $\mathrm{N}_{2}$-fixing community dynamics: $\mathrm{N}_{2}$-fixing communities in agricultural soils. Environ. Microbiol. doi: 10.1111/1462-2920.12423 [Epub ahead of print].

Conn, V. M., Walker, A. R., and Franco, C. M. (2008). Endophytic actinobacteria induce defense pathways in Arabidopsis thaliana. Mol. Plant Microbe Interact. 21, 208-218. doi: 10.1094/MPMI-21-2-0208

Crotti, E., Rizzi, A., Chouaia, B., Ricci, I., Favia, G., Alma, A., et al. (2010). Acetic acid bacteria, newly emerging symbionts of insects. Appl. Environ. Microbiol. 76, 6963-6970. doi: 10.1128/AEM.01336-10

DeLuca, T. H., Zackrisson, O., Nilsson, M. C., and Sellstedt, A. (2002). Quantifying nitrogen-fixation in feather moss carpets of boreal forests. Nature 419, 917-920. doi: 10.1038/nature01051

Delwiche, C., Zinke, P. J., Johnson, C. M., and Virginia, R. A. (1979). Nitrogen isotope distribution as a presumptive indicator of nitrogen fixation. Bot. Gaz. 140, 65-69. doi: 10.1086/337037

DeSantis, T. Z., Hugenholtz, P., Larsen, N., Rojas, M., Brodie, E. L., Keller, K., et al. (2006). Greengenes, a chimera-checked 16S rRNA gene database and workbench compatible with ARB. Appl. Environ. Microbiol. 72, 5069-5072. doi: 10.1128/AEM.03006-05

Dong, Z., Canny, M. J., McCully, M. E., Roboredo, M. R., Cabadilla, C. F., Ortega, E., et al. (1994). A nitrogen-fixing endophyte of sugarcane stems (a new role for the apoplast). Plant Physiol. 105, 1139-1147.

Dutta, D., and Gachhui, R. (2006). Novel nitrogen-fixing Acetobacter nitrogenifigens sp. nov., isolated from Kombucha tea. Int. J. Syst. Evol. Microbiol. 56, 1899-1903. doi: 10.1099/ijs.0.64101-64100

Dutta, D., and Gachhui, R. (2007). Nitrogen-fixing and cellulose-producing Gluconacetobacter kombuchae sp. nov., isolated from Kombucha tea. Int. J. Syst. Evol. Microbiol. 57, 353-357. doi: 10.1099/ijs.0.64638-0

Edgar, R. C. (2010). Search and clustering orders of magnitude faster than BLAST. Bioinformatics 26, 2460-2461. doi: 10.1093/bioinformatics/btq461

Edgar, R. C., Haas, B. J., Clemente, J. C., Quince, C., and Knight, R. (2011). UCHIME improves sensitivity and speed of chimera detection. Bioinformatics 27, 2194 2200. doi: 10.1093/bioinformatics/btr381

Engel, P., and Moran, N. A. (2013). The gut microbiota of insects-diversity in structure and function. FEMS Microbiol. Rev. 37, 699-735. doi: 10.1111/15746976.12025

Farnelid, H., Bentzon-Tilia, M., Andersson, A. F., Bertilsson, S., Jost, G., Labrenz, M., et al. (2013). Active nitrogen-fixing heterotrophic bacteria at and below the chemocline of the central Baltic Sea. ISME J. 7, 1413-1423. doi: 10.1038/ismej.2013.26

Favilli, F., and Messini, A. (1990). Nitrogen fixation at phyllospheric level in coniferous plants in Italy. Plant Soil 128, 91-95. doi: 10.1007/BF00009400

Fuentes-Ramirez, L. E., Bustillos-Cristales, R., Tapia-Hernandez, A., JimenezSalgado, T., Wang, E. T., Martinez-Romero, E., et al. (2001). Novel nitrogen-fixing acetic acid bacteria, Gluconacetobacter johannae sp. nov. and Gluconacetobacter azotocaptans sp. nov., associated with coffee plants. Int. J. Syst. Evol. Microbiol. 51, 1305-1314.

Gillis, M., Kersters, K., Hoste, B., Janssens, D., Kroppenstedt, R. M., Stephan, M. P., et al. (1989). Acetobacter diazotrophicus sp. nov., a nitrogen-fixing acetic acid bacterium associated with sugarcane. Int. J. Syst. Bacteriol. 39, 361-364. doi: 10.1099/00207713-39-3-361

Glick, B. R. (2004). Bacterial ACC deaminase and the alleviation of plant stress. $A d v$. Appl. Microbiol. 56, 291-312. doi: 10.1016/S0065-2164(04)56009-4

Gottel, N. R., Castro, H. F., Kerley, M., Yang, Z., Pelletier, D. A., Podar, M., et al. (2011). Distinct microbial communities within the endosphere and rhizosphere of Populus deltoides roots across contrasting soil types. Appl. Environ. Microbiol. 77, 5934-5944. doi: 10.1128/AEM.05255-11

Greenberg, D. E., Ding, L., Zelazny, A. M., Stock, F., Wong, A., Anderson, V. L., et al. (2006). A novel bacterium associated with lymphadenitis in a patient with chronic granulomatous disease. PLoS Pathog. 2:e28. doi: 10.1371/journal.ppat. 0020028

Hallman, J., Quadt-Hallmann, A., Mahaffee, W. F., and Kloepper, J. W. (1997). Bacterial endophytes in agricultural crops. Can. J. Microbiol. 43, 895-914. doi: 10.1139/m97-131

Hanshew, A. S., Mason, C. J., Raffa, K. F., and Currie, C. R. (2013). Minimization of chloroplast contamination in 16S rRNA gene pyrosequencing of insect herbivore bacterial communities. J. Microbiol. Methods 95, 149-155. doi: 10.1016/j.mimet.2013.08.007

Hardoim, P. R., van Overbeek, L. S., and Elsas, J. D. (2008). Properties of bacterial endophytes and their proposed role in plant growth. Trends Microbiol. 16, 463471. doi: 10.1016/j.tim.2008.07.008

Higgins, K. L., Coley, P. D., Kursar, T. A., and Arnold, A. E. (2011). Culturing and direct PCR suggest prevalent host generalism among diverse fungal endophytes of tropical forest grasses. Mycologia 103, 247-260. doi: 10.3852/09-158

Hobbie, E. A., Macko, S. A., and Williams, M. (2000). Correlations between foliar $\delta 15 \mathrm{~N}$ and nitrogen concentrations may indicate plant-mycorrhizal interactions. Oecologia 273-283. doi: 10.1007/PL00008856

Hurek, T., Handley, L. L., Reinhold-Hurek, B., and Piche, Y. (2002). Azoarcus grass endophytes contribute fixed nitrogen to the plant in an unculturable state. Mol. Plant Microbe Interact. 15, 233-242. doi: 10.1094/MPMI.2002.15.3.233

Idris, R., Trifonova, R., Puschenreiter, M., Wenzel, W. W., and Sessitsch, A. (2004). Bacterial communities associated with flowering plants of the Ni hyperaccumulator Thlaspi goes ingense. Appl. Environ. Microbiol. 70, 2667-2677. doi: 10.1128/AEM.70.5.2667-2677.2004

Izumi, H., Anderson, I. C., Killham, K., and Moore, E. R. (2008). Diversity of predominant endophytic bacteria in European deciduous and coniferous trees. Can. J. Microbiol. 54, 173-179. doi: 10.1139/W07-134

Jiao, J. Y., Wang, H. X., Zeng, Y., and Shen, Y. M. (2006). Enrichment for microbes living in association with plant tissues. J. Appl. Microbiol. 100, 830-837. doi: 10.1111/j.1365-2672.2006.02830.x

Jojima, Y., Mihara, Y., Suzuki, S., Yokozeki, K., Yamanaka, S., and Fudou, R. (2004). Saccharibacter floricola gen. nov., sp. nov., a novel osmophilic acetic acid bacterium isolated from pollen. Int. J. Syst. Evol. Microbiol. 54, 2263-2267. doi: 10.1099/ijs.0.02911-0

Jones, K., King, E., and Eastlick, M. (1974). Nitrogen fixation by free-living bacteria in the soil and in the canopy of Douglas fir. Ann. Bot. Lond. 38, 765-762.

Kersters, K., Lisdiyanti, P., Komagata, K., and Swings, J. (2006). "The family Acetobacteraceae: the genera Acetobacter, Acidomonas, Asaia, Gluconacetobacter, Gluconobacter, and Kozakia," in The Prokaryotes, eds M. Dworkin, S. Falkow, E. Rosenberg, K. H. Schleifer, and E. Stackebrandt (New York, NY: Springer), 163-200.

Knoth, J. L., Kim, S. H., Ettl, G. J., and Doty, S. L. (2013). Biological nitrogen fixation and biomass accumulation within poplar clones as a result of inoculations with diazotrophic endophyte consortia. New Phytol. doi: 10.1111/nph.12536 [Epub ahead of print].

Lee, S., Flores-Encarnación, M., Contreras-Zentella, M., Garcia-Flores, L., Escamilla, J. E., and Kennedy, C. (2004). Indole-3-acetic acid biosynthesis is deficient in Gluconacetobacter diazotrophicus strains with mutations in cytochrome c biogenesis genes. J. Bacteriol. 186, 5384-5391. doi: 10.1128/JB.186.16.53845391.2004

Lin, C.-P., Huang, J.-P., Wu, C.-S., Hsu, C.-Y., and Chaw, S.-M. (2010). Comparative chloroplast genomics reveals the evolution of Pinaceae genera and subfamilies. Genome Biol. Evol. 2, 504-517. doi: 10.1093/gbe/evq036

Lipson, D. A., and Schmidt, S. K. (2004). Seasonal changes in an alpine soil bacterial community in the colorado rocky mountains. Appl. Environ. Microbiol. 70, 28672879. doi: 10.1128/AEM.70.5.2867-2879.2004

Loganathan, P., and Nair, S. (2004). Swaminathania salitolerans gen. nov., sp. nov., a salt-tolerant, nitrogen-fixing and phosphate-solubilizing bacterium from wild rice (Porteresia coarctata Tateoka). Int. J. Syst. Evol. Microbiol. 54, 1185-1190. doi: 10.1099/ijs.0.028170

Lundberg, D. S., Lebeis, S. L., Paredes, S. H., Yourstone, S., Gehring, J., Malfatti, S., et al. (2012). Defining the core Arabidopsis thaliana root microbiome. Nature 488, 86-90. doi: 10.1038/nature11237

Martinson, V. G., Danforth, B. N., Minckley, R. L., Rueppell, O., Tingek, S., and Moran, N. A. (2011). A simple and distinctive microbiota associated with honey bees and bumble bees. Mol. Ecol. 20, 619-628. doi: 10.1111/j.1365-294X.2010.04959.x 
Mayak, S., Tirosh, T., and Glick, B. R. (2004). Plant growth-promoting bacteria confer resistance in tomato plants to salt stress. Plant Physiol. Biochem. 42, 565572. doi: 10.1016/j.plaphy.2004.05.009

Morford, S. L., Houlton, B. Z., and Dahlgren, R. A. (2011). Increased forest ecosystem carbon and nitrogen storage from nitrogen rich bedrock. Nature 477, 78-81. doi: $10.1038 /$ nature 10415

Muthukumarasamy, R., Cleenwerck, I., Revathi, G., Vadivelu, M., Janssens, D., Hoste, B., et al. (2005). Natural association of Gluconacetobacter diazotrophicus and diazotrophic Acetobacter peroxydans with wetland rice. Syst. Appl. Microbiol. 28, 277-286. doi: 10.1016/j.syapm.2005.01.006

Näsholm, T., Kielland, K., and Ganeteg, U. (2009). Uptake of organic nitrogen by plants. New Phytol. 182, 31-48. doi: 10.1111/j.1469-8137.2008.02751.x

Oksanen, J., Kindt, P., Legendre, B., O’Hara, B., Simpson, G. L., and Stevenson, M. H. H. (2008), vegan: Community Ecology Package, R Package Version 1.11-4. Available at: http://cran.r-project.org/

Ping, L., and Boland, W. (2004). Signals from the underground: bacterial volatiles promote growth in Arabidopsis. Trends Plant Sci. 9, 263-266. doi 10.1016/j.tplants.2004.04.008

Pirttilä, A., and Frank, A. C. (2011). Endophytes of Forest Trees: Biology and Application. Dordrecht: Springer. doi: 10.1007/978-94-007-1599-8

Pirttilä, A. M., Joensuu, P., Pospiech, H., Jalonen, J., and Hohtola, A. (2004). Bud endophytes of Scots pine produce adenine derivatives and other compounds that affect morphology and mitigate browning of callus cultures. Physiol. Plant. 121, 305-312. doi: 10.1111/j.0031-9317.2004.00330.x

Pirttilä, A. M., Laukkanen, H., Pospiech, H., Myllyla, R., and Hohtola, A. (2000) Detection of intracellular bacteria in the buds of Scotch pine (Pinus sylvestri L.) by in situ hybridization. Appl. Environ. Microbiol. 66, 3073-3077. doi: 10.1128/AEM.66.7.3073-3077.2000

Pirttilä, A. M., Pospiech, H., Laukkanen, H., Myllyla, R., and Hohtola, A. (2005). Seasonal variations in location and population structure of endophytes in buds of Scots pine. Tree Physiol. 25, 289-297. doi: 10.1093/treephys/25. 3.289

Poole, A. M., Stouffer, D. B., and Tylianakis, J. M. (2012). “Ecosystomics": ecology by sequencer. Trends Ecol. Evol. 27, 309-310. doi: 10.1016/j.tree.2012.03.008

Price, M. N., Dehal, P. S., and Arkin, A. P. (2009). FastTree: computing large minimum evolution trees with profiles instead of a distance matrix. Mol. Biol. Evol. 26, 1641-1650. doi: 10.1093/molbev/msp077

Qin, J., Li, R., Raes, J., Arumugam, M., Burgdorf, K. S., Manichanh, C., et al. (2010). A human gut microbial gene catalogue established by metagenomic sequencing. Nature 464, 59-65. doi: 10.1038/nature08821

Rastogi, G., Sbodio, A., Tech, J. J., Suslow, T. V., Coaker, G. L., and Leveau, J. H. (2012). Leaf microbiota in an agroecosystem: spatiotemporal variation in bacterial community composition on field-grown lettuce. ISME J. 6, 1812-1822. doi: 10.1038/ismej.2012.32

Redford, A. J., Bowers, R. M., Knight, R., Linhart, Y., and Fierer, N. (2010). The ecology of the phyllosphere: geographic and phylogenetic variability in the distribution of bacteria on tree leaves. Environ. Microbiol. 12, 2885-2893. doi: 10.1111/j.1462-2920.2010.02258.x

Reed, S. C., Townsend, A. R., Cleveland, C. C., and Nemergut, D. (2010). Microbial community shifts influence patterns in tropical forest nitrogen fixation. Oecologia 264, 521-531. doi: 10.1007/s00442-010-1649-6

Reiter, B., Bürgmann, H., Burg, K., and Sessitsch, A. (2003). Endophytic nifH gene diversity in African sweet potato. Can. J. Microbiol. 49, 549-555. doi: 10.1139/w03-070

Richards, B. N. (1964). Fixation of atmospheric nitrogen in coniferous forests. Aust. For. 28, 68-74. doi: 10.1080/00049158.1964.10675356

Roh, S. W., Nam, Y. D., Chang, H. W., Kim, K. H., Kim, M. S., Ryu, J. H., et al. (2008) Phylogenetic characterization of two novel commensal bacteria involved with innate immune homeostasis in Drosophila melanogaster. Appl. Environ. Microbiol. 74, 6171-6177. doi: 10.1128/AEM.00301-08

Rout, M. E., Chrzanowski, T. H., Westlie, T. K., Deluca, T. H., Callaway, R. M., and Holben, W. E. (2013). Bacterial endophytes enhance competition by invasive plants. Am. J. Bot. 100, 1726-1737. doi: 10.3732/ajb. 1200577

Rueth, H. M., and Baron, J. S. (2002). Differences in Englemann Spruce forest biogeochemistry East and West of the continental divide in Colorado, USA. Ecosystems 5, 45-57. doi: 10.1007/s10021-001-0054-8
Schlaeppi, K., Dombrowski, N., Oter, R. G., Ver Loren van Themaat, E., and SchulzeLefert, P. (2014). Quantitative divergence of the bacterial root microbiota in Arabidopsis thaliana relatives. Proc. Natl. Acad. Sci. U.S.A. 111, 585-592. doi: 10.1073/pnas.1321597111

Schoettle, A. W., and Rochelle, S. G. (2000). Morphological variation of Pinus flexilis (Pinaceae), a bird-dispersed pine, across a range of elevations. Am. J. Bot. 87, 1797-1806. doi: 10.2307/2656832

Shade, A., and Handelsman, J. (2012). Beyond the Venn diagram: the hunt for a core microbiome. Environ. Microbiol. 14, 4-12. doi: 10.1111/j.1462-2920.2011.02585.x

Sharp, K. H., Distel, D., and Paul, V. J. (2012). Diversity and dynamics of bacterial communities in early life stages of the Caribbean coral Porites astreoides. ISME J. 6, 790-801. doi: 10.1038/ismej.2011.144

Smith, S., and Read, D. (2008). Mycorrhizal Symbiosis. London: Academic Press.

Stamatakis, A., Ludwig, T., and Meier, H. (2005). RAxML-III: a fast program for maximum likelihood-based inference of large phylogenetic trees. Bioinformatics 21, 456-463. doi: 10.1093/bioinformatics/bti191

Ueda, T., Suga, Y., Yahiro, N., and Matsuguchi, T. (1995). Remarkable $\mathrm{N}_{2}$-fixing bacterial diversity detected in rice roots by molecular evolutionary analysis of nifH gene sequences. J. Bacteriol. 177, 1414-1417.

Verma, S. C., Ladha, J. K., and Tripathi, A. K. (2001). Evaluation of plant growth promoting and colonization ability of endophytic diazotrophs from deep water rice. J. Biotechnol. 91, 127-141. doi: 10.1016/S0168-1656(01)00333-9

Virginia, R. A., and Delwiche, C. (1982). Natural $15 \mathrm{~N}$ abundance of presumed $\mathrm{N}_{2}$-fixing plants from selected ecosystems. Oecologia 54, 317-325. doi: 10.1007/BF00380000

Vitousek, P. M., Menge, D. N., Reed, S. C., and Cleveland, C. C. (2013). Biological nitrogen fixation: rates, patterns and ecological controls in terrestrial ecosystems. Philos. Trans. R. Soc. Lond. B Biol. Sci. 368, 20130119. doi: 10.1098/rstb.2013.0119

Wakelin, S. A., Warren, R. A., Harvey, P. R., and Ryder, M. H. (2004). Phosphate solubilization by Penicillium spp. closely associated with wheat roots. Biol. Fertil. Soils 40, 36-43. doi: 10.1007/s00374-004-0750-6

Wang, Q., Garrity, G. M., Tiedje, J. M., and Cole, J. R. (2007). Naive Bayesian classifier for rapid assignment of rRNA sequences into the new bacterial taxonomy. Appl. Environ. Microbiol. 73, 5261-5267. doi: 10.1128/AEM.00062-07

Woebken, D., Prufert-Bebout, L., Burow, L., Bebout, B., Hoehler, T., Pett-Ridge, J., et al. (2012). Identification of a previously unknown cyanobacterial group as active diazotrophs in coastal microbial mats using NanoSIMS. ISME J. 6, 14271439. doi: 10.1038/ismej.2011.200

Yukphan, P., Malimas, T., Muramatsu, Y., Takahashi, M., Kaneyasu, M., Potacharoen, W., et al. (2009). Ameyamaea chiangmaiensis gen. nov., sp. nov., an acetic acid bacterium in the alpha-Proteobacteria. Biosci. Biotechnol. Biochem. 73, 21562162. doi: 10.1271/bbb. 90070

Yukphan, P., Malimas, T., Muramatsu, Y., Takahashi, M., Kaneyasu, M., Tanasupawat, S., et al. (2008). Tanticharoenia sakaeratensis gen. nov., sp. nov., a new osmotolerant acetic acid bacterium in the alpha-Proteobacteria. Biosci. Biotechnol. Biochem. 72, 672-676. doi: 10.1271/bbb.70319

Yukphan, P., Malimas, T., Potacharoen, W., Tanasupawat, S., Tanticharoen, M., and Yamada, Y. (2005). Neoasaia chiangmaiensis gen. nov., sp. nov., a novel osmotolerant acetic acid bacterium in the alpha-Proteobacteria. J. Gen. Appl. Microbiol. 51, 301-311. doi: 10.2323/jgam.51.301

Conflict of Interest Statement: The authors declare that the research was conducted in the absence of any commercial or financial relationships that could be construed as a potential conflict of interest.

Received: 16 May 2014; accepted: 16 June 2014; published online: 04 July 2014. Citation: Carrell AA and Frank AC (2014) Pinus flexilis and Picea engelmannii share a simple and consistent needle endophyte microbiota with a potential role in nitrogen fixation. Front. Microbiol. 5:333. doi: 10.3389/fmicb.2014.00333

This article was submitted to Plant-Microbe Interaction, a section of the journal Frontiers in Microbiology.

Copyright (c) 2014 Carrell and Frank. This is an open-access article distributed under the terms of the Creative Commons Attribution License (CC BY). The use, distribution or reproduction in other forums is permitted, provided the original author(s) or licensor are credited and that the original publication in this journal is cited, in accordance with accepted academic practice. No use, distribution or reproduction is permitted which does not comply with these terms. 